\title{
PEMBERDAYAAN KOMITE SEKOLAH: KAJIAN KONSEP DAN IMPLEMENTASINYA
}

\author{
Yunita Endra Megiati \\ Program Studi Teknik Informatika, Universitas Indraprasta PGRI \\ Email: megiati_igem@yahoo.com
}

\begin{abstract}
Abstrak
Dasar dibentuknya Komite Sekolah dan Dewan Pendidikan adalah adanya perubahan paradigma pemerintahan dari sentralisasi ke desentralisasi yang esensinya membuka peluang masyarakat untuk dapat meningkatkan peran serta dalam pengelolaan pendidikan. Pemerintah menyadari bahwa dalam rangka mencapai tujuan pendidikan nasional melalui upaya peningkatan mutu, pemerataan, efisiensi penyelenggaraan pendidikan, dan demokratisasi pendidikan, perlu adanya dukungan dan peran serta masyarakat yang lebih optimal. Metode yang digunakan dalam penelitian adalah kualitatif berdasarkan studi kepustakaan. Simpulan dari penelitian ini adalah keberadaan Komite Sekolah dan Dewan Pendidikan sesungguhnya merupakan sebuah harapan besar dalam pengembangan sekolah dan pemberdayaan masyarakat. Komite Sekolah dan Dewan Pendidikan dibentuk dengan maksud agar yang diharapkan oleh masyarakat dapat dilaksanakan oleh sekolah, yakni kelak ketika peserta didik atau anak telah berada dalam lingkungan masyarakat dapat bersikap dan berperilaku sesuai dengan harapan anggota masyarakat lainnya.
\end{abstract}

Kata Kunci: Pemberdayaan, Stakeholder, Komite Sekolah

\section{Pendahuluan}

Pelibatan masyarakat di dalam pendidikan sangat diperlukan dan diharapkan tidak dalam bentuk konsep dan wacana saja, tetapi lebih pada praktek di lapangan. Selama ini pelibatan masyarakat dalam pendidikan hanya pada tataran konsep, wacana, atau slogan. Keterlibatan masyarakat yang diinginkan masih jauh dari apa yang diharapkan. Secara resmi konsep Komite Sekolah dan Dewan Pendidikan mulai digulirkan sejak 2 April 2002, melalui Keputusan Menteri Pendidikan Nasional No. 044/U/2002, meski fungsinya secara spesifik lokal telah ada yang menjalankannya jauh lebih dahulu. Konsep pelibatan masyarakat dalam penyelenggaraan sekolah yang terkandung di dalamnya memerlukan pemahaman berbagai pihak terkait, terutama menyangkut posisi dan apa manfaatnya. Dalam UU Nomor 25 Tahun 2000 tentang PROPENAS, pada butir 4 disebutkan perlunya peningkatan partisipasi keluarga dan masyarakat dalam penyelenggaraan pendidikan. Upaya tersebut antara lain dilaksanakan pemerintah dengan membentuk Komite Sekolah dan Dewan Pendidikan dan tujuan utamanya untuk ikut meningkatkan tanggung jawab dan peran aktif dari seluruh lapisan masyarakat dalam penyelenggaraan pendidikan.

Komite Sekolah merupakan sebuah badan mandiri yang mewadahi peran serta masyarakat dalam rangka meningkatkan mutu, pemerataan dan efisiensi pengelolaan pendidikan di satuan pendidikan baik pada pendidikan prasekolah, jalur pendidikan sekolah, maupun jalur pendidikan luar sekolah. Untuk penamaan badan disesuaikan dengan kondisi dan kebutuhan daerah masing-masing satuan pendidikan, seperti Komite Sekolah, Majelis Madrasah, Majelis Sekolah, Komite TK, atau nama-nama lain yang disepakati bersama. Komite Sekolah berkedudukan di setiap satuan pendidikan, merupakan badan mandiri yang tidak memiliki hubungan hierarkis dengan lembaga pemerintahan. Komite Sekolah dapat terdiri dari satuan pendidikan atau berupa satuan pendidikan dalam jenjang yang sama, atau beberapa satuan pendidikan yang berbeda jenjang tetapi berada pada lokasi yang berdekatan, atau satuan-satuan pendidikan yang dikelola oleh suatu penyelenggara pendidikan, atau dapat karena pertimbangan lainnya. (Hasbullah, 2007) 
Komite Sekolah merupakan media bersama bagi orang-orang yang peduli, ikhlas, dan tanpa pamrih berjuang untuk kepentingan peningkatan kualitas pendidikan dan akses masyarakat miskin memperoleh pendidikan yang layak. Anggota Komite Sekolah harus memiliki prinsip: kerelawanan, kepedulian, keikhlasan, kepentingan bersama, dan kepercayaan bukan pada status, jabatan, latar belakang, atau simbol-simbol lainnya. (Saepudin, 2009). Tujuan dari keberadaan Komite Sekolah dan Dewan Pendidikan tidak sekedar alat untuk memperjuangkan kepentingan pribadi atau kelompoknya, juga tidak sebagai sarana untuk memperoleh status, jabatan, posisi, materi, atau hak-hak istimewa, tetapi aktualisasi tanggungjawab masyarakat dalam memajukan sekolah. Komite Sekolah bertanggungjawab dalam penyusunan perencanaan strategi dan tahunan sekolah, perumusan kebijaksanaan sekolah, pemenuhan kebutuhan sekolah, anggaran sekolah, ikut memantau kegiatan keseharian sekolah, menilai keberhasilan pelaksanaan program-program yang dilaksanakan sekolah serta ikut mensahkan laporan tahunan sekolah. (Saepudin, 2009). Sedangkan Dewan Pendidikan sebagai lembaga mandiri yang dibentuk dan berperan dalam peningkatan mutu pelayanan pendidikan dengan memberikan pertimbangan, arahan, dan dukungan tenaga, sarana dan prasarana, serta pengawasan pendidikan pada tingkat nasional, propinsi, dan kabupaten /kota yang tidak mempunyai hubungan hierarkis. Atas dasar untuk pemberdayaan masyarakat, maka digulirkan konsep Komite Sekolah sebagaimana dikemukakan di atas. Namun untuk dapat memberdayakan dan meningkatkan peran masyarakat, pihak sekolah harus dapat membina kerja sama dengan orang tua dan masyarakat dengan cara menciptakan suasana kondusif dan menyenangkan bagi peserta didik dan warga sekolah.

Peneliti melihat ada masalah atau persoalan yang selama ini dihadapi, yakni Komite Sekolah dianggap hanyalah sebagai bagian formalitas semata, dan pihak orang tua atau wali murid juga tidak mengetahui secara mendalam fungsi dan peran Komite Sekolah di satuan pendidikan. Banyak yang beranggapan bahwa Komite Sekolah memiliki peran seperti BP3 di masa lampau, yaitu sebagai badan yang bertugas sebagai pengumpul dana bantuan untuk pendidikan atau menganggap Komite Sekolah hanya semacam badan justifikasi belaka. Peneliti berasumsi bahwa jika Komite Sekolah dapat melaksanakan keempat perannya secara baik, maka Komite Sekolah tersebut dapat memberikan dampak terhadap kinerja sistem pendidikan yang ada. Melalui penelitian ini, dapat diketahui keberadaan dan peran Komite Sekolah menyentuh berbagai indikator kinerja yang berkaitan dengan keberhasilan sistem pendidikan persekolahan dalam upaya memberikan pelayanan kepada masyarakat secara optimal.

\section{Tinjauan Pustaka}

\section{Hakikat Pemberdayaan}

Menurut Merriam Webster dan Oxford-English Dictionary (dalam Saepudin, 2000) kata empower mengandung dua arti. Pengertian pertama adalah to give power or authority to. Pengertian kedua mengandung arti to give ability or enable. Menurut Jamasy (dalam Saepudin, 2004) arti pemberdayaan itu tidak hanya sekedar memberi kekuasaan itu terhadap pihak tersebut. Menurutnya kata empowering menjadi 'power' yang berarti kontrol, kekuasaan, dominion, dan awalan 'em' yang berarti mengenakan atau menutupi dengan. Perubahan tersebut dapat terjadi karena pemberdayaan memang merupakan upaya untuk mendorong pihak yang tidak berdaya agar mengalami perubahan. Dalam lingkup individu, pemberdayaan merupakan suatu konsep yang menjelaskan berbagai upaya untuk memperkuat posisi seseorang dalam melalui penumbuhan kesadaran dan kemampuan individu yang bersangkutan untuk mengidentifikasi persoalan yang dihadapi dan memikirkan langkah-langkah mengatasinya. Inti dari kegiatan pemberdayaan dalam lingkup ini adalah motivasi untuk memahami kondisi dan situasi kerja sehari-hari serta menumbuhkan kemampuan dan keberanian seseorang untuk bersikap kritis terhadap kondisi yang mereka hadapi, sehingga kuncinya adalah membangun partisipasi. Sedangkan dalam lingkup yang lebih luas, Hulme dan Turner (dalam Saepudin, 2009) mengemukakan bahwa pemberdayaan 
mendorong terjadinya suatu proses perubahan sosial yang memungkinkan orang-orang pinggiran yang tidak berdaya untuk memberikan pengaruh yang lebih besar di arena politik secara lokal maupun nasional. Oleh karena itu, pemberdayaan sifatnya individual sekaligus kolektif.

Sejalan dengan pendapat di atas, menurut Aileen Mitchell Stewart (dalam Saepudin, 2009), pemberdayaan dimaknai sebagai upaya yang dilakukan untuk: (1) membuat mampu (enabling), yakni memastikan bahwa individu atau kelompok mempunyai segala sumber daya yang mereka perlukan untuk diberdayakan secara penuh; (2) memperlancar (facilitating), yakni meniadakan segala halangan, rintangan, dan penundaan yang menghalangi individu untuk melakukan pekerjaan dengan sebaik-baiknya. Halangan itu bisa berupa kurang memadainya informasi, kecakapan, atau pengetahuan; (3) berkonsultasi (consulting), dalam memecahkan masalah yang dihadapi individu sehari-hari; (3) bekerja sama (collaborating), antara pelaku pemberdayaan dengan peserta yang diberdayakan; (4) membimbing (mentoring), yang dilakukan pelaku pemberdayaan bagi peserta sehingga mereka dapat berkembang seperti pembimbingnya, dan; (5) mendukung (supporting), yang dilakukan selama proses pemberdayaan.

\section{Karakteristik Pemberdayaan}

Pemberdayaan berasal dari kata daya, yang berarti kemampuan melakukan sesuatu atau kemampuan untuk untuk bertindak, dan pemberdayaan itu sendiri adalah proses, cara, perbuatan memberdayakan. (KBBI, 2005). Ditinjau dari karakteristiknya, istilah pemberdayaan selain merupakan suatu proses yang menyangkut hubungan-hubungan kekuasaan atau kekuatan yang berubah antara individu, kelompok dan lembaga-lembaga sosial juga merupakan proses perubahan pribadi karena masing-masing individu mengambil tindakan atas nama mereka sendiri dan kemudian kembali pemahamannya terhadap dunia tempat ia tinggal. Persepsi diri bergerak dari korban (victim) ke pelaku (agent) karena orang mampu bertindak dalam arena sosial politik dan berusaha memenuhi kepentingannya. (Saepudin, 2009). Disimpulkan bahwa pemberdayaan adalah suatu proses dalam upaya untuk memperkuat posisi seseorang atau masyarakat dalam menumbuhkan kesadaran dan kemampuan individu atau masyarakat yang bersangkutan untuk mengidentifikasi persoalan yang dihadapi dan memikirkan langkah-langkah mengatasinya.

\section{Hakikat Komite Sekolah}

Undang-Undang Sistem Pendidikan Nasional Nomor 20 Tahun 2003 pasal 56 ayat 3 menyatakan bahwa Komite Sekolah sebagai lembaga mandiri dibentuk dan berperan dalam peningkatan mutu pelayanan dengan memberikan pertimbangan, arahan, dan dukungan tenaga, sarana dan prasarana serta pengawasan pendidikan pada tingkat satuan pendidikan. Maka setiap lembaga pendidikan pada tingkat satuan pendidikan diharuskan membentuk Komite Sekolah atau Dewan Sekolah guna mewadahi dan menyalurkan aspirasi serta prakarsa masyarakat dalam melahirkan kebijakan operasional dan program pendidikan di tingkat satuan pendidikan tersebut. Dalam Kepmediknas nomor: 044/U/2002 ditegaskan bahwa Komite Sekolah adalah Badan mandiri yang mewadahi peran serta masyarakat dalam rangka meningkatkan mutu, pemerataan, dan efisiensi pengelolaan pendidikan di satuan pendidikan, baik pada pendidikan prasekolah, jalur pendidikan sekolah, maupun luar sekolah. Nama dan ruang lingkup kewenangan wadah ini disesuaikan dengan kondisi dan kebutuhan masing-masing satuan pendidikan, misalnya: komite sekolah, komite pendidikan, komite pendidikan luar sekolah, dewan sekolah, majelis sekolah atau madrasah, komite taman kanak-kanak, atau nama lain yang sesuai dengan pemberdayaan masyarakat dan pemberdayaan sekolah. Adapun esensi dari partisipasi Komite Sekolah adalah meningkatkan kualitas pengambilan keputusan dan perencanaan sekolah yang dapat mengubah pola pikir, keterampilan, dan distribusi kewenangan atas individual dan masyarakat yang dapat 
memperluas kapasitas manusia dan meningkatkan taraf hidup dalam sistem manajemen pemberdayaan sekolah.

Keberadaan Komite Sekolah bersama Dewan Pendidikan secara legal formal telah dituangkan dalam Keputusan Menteri Pendidikan Nasional Nomor 044/U/2002, dimana keberadaan Komite Sekolah dapat berperan sebagai berikut :

1. Pemberi pertimbangan (advisory agency) dalam penentuan dan pelaksanaan kebijakan pendidikan di satuan pendidikan, minimal dalam memberikan masukan, pertimbangan, dan rekomendasi kepada satuan pendidikan. Tujuannya supaya masukan tersebut sesuai dengan kebutuhan satuan pendidikan.

2. Pendukung (supporting agency) baik yang berwujud finansial, pemikiran, maupun tenaga dalam penyelenggaraan pendidikan di satuan pendidikan, minimal dalam mendorong tumbuhnya perhatian dan komitmen masyarakat terhadap penyelenggaraan pendidikan yang bermutu.

3. Pengontrol (controlling agency) dalam rangka transparansi dan akuntabilitas penyelenggaraan dan keluaran pendidikan di satuan pendidikan, minimal melakukan evaluasi dan pengawasan terhadap kebijakan, program, penyelenggaraan, dan keluaran pendidikan dari satuan pendidikan.

4. Mediator antara pemerintah (eksekutif) dan dengan masyarakat di satuan pendidikan, terutama dalam melakukan kerja sama dengan masyarakat baik perorangan, organisasi pemerintahan dan kemasyarakatan untuk penyelenggaraan pendidikan dan pembelajaran bermutu. Selain itu, mediator juga memberikan makna untuk menampung dan menganalisis aspirasi, ide, tuntutan dan berbagai kebutuhan pendidikan yang diajukan oleh masyarakat. (Saepudin, 2009)

Posisi Komite Sekolah berada di tengah-tengah antara orang tua murid, murid, guru, masyarakat setempat dan kalangan swasta di satu pihak dengan pihak sekolah sebagai institusi, kepala sekolah, dinas pendidikan wilayah, dan pemerintah daerah di pihak lainnya. Ketika ada keluhan masyarakat yang masuk, maka disinilah posisi dan peran Komite Sekolah yang perlu dikenalkan manfaatnya. Peran Komite sekolah diharapkan dapat menjembatani kepentingan keduanya.

Pembentukan Komite Sekolah didasarkan prakarsa masyarakat yang peduli pendidikan dan tidak berdasarkan instruksi dari lembaga pemerintah. Oleh karena itu, sebaiknya pembentukan Komite Sekolah didasarkan kepada prinsip-prinsip sebagai berikut: (1) Komite Sekolah dibentuk berdasarkan prakarsa masyarakat yang peduli pendidikan, pembentukan Komite Sekolah dilakukan secara transparan atau terbuka, diketahui oleh masyarakat khususnya yang ada di lingkungan sekolah mulai dari tahap pembentukan panitia persiapan, sosialisasi, penentuan kriteria calon anggota, proses pemilihan, sampai penyampaian hasil pemilihan. (2) Akuntabel, pembentukan Komite Sekolah yang dilakukan oleh panitia persiapan harus dapat dipertanggungjawabkan kepada masyarakat secara substansi maupun finansial. (3) Demokratis, pembentukan Komite Sekolah dilakukan dengan melibatkan seluruh masyarakat khususnya di lingkungan sekolah, baik secara musyawarah mufakat maupun melalui pemungutan suara. (Saepudin, 2009)

\section{Peranan dan Fungsi Komite Sekolah}

Dalam Undang-undang Nomor 20 Tahun 2003 tentang Sistem Pendidikan Nasional pasal 54 dikemukakan: (1) Peran serta masyarakat dalam pendidikan meliputi peran serta perorangan, kelompok, keluarga, organisasi profesi, pengusaha, dan organisasi kemasyarakatan dalam penyelenggaraan dan pengendalian mutu pelayanan pendidikan; (2) Masyarakat dapat berperan serta sebagai sumber, pelaksana, dan pengguna hasil pendidikan. Adapun Komite Sekolah merupakan badan mandiri yang mewadahi peran serta masyarakat dalam rangka 
meningkatkan mutu, pemerataan dan efisiensi pengelolaan pendidikan di satuan pendidikan baik pada pendidikan prasekolah, jalur pendidikan sekolah, maupun jalur pendidikan luar sekolah. Dan anggota-anggota Komite Sekolah terdiri dari kepala sekolah, dewan guru, orang tua siswa dan masyarakat. Dan yang dimaksud dengan Dewan Pendidikan adalah badan yang mewadahi peran serta masyarakat dalam rangka meningkatkan mutu, pemerataan, dan efisiensi pengelolaan pendidikan di kabupaten/kota. Keanggotaan Dewan Pendidikan terdiri dari (1) Unsur masyarakat, seperti LSM, tokoh masyarakat, tokoh pendidikan, yayasan penyelenggara pendidikan, dunia usaha/industri/asosiasi profesi, organisasi profesi tenaga pendidikan, dan komite sekolah; (2) Unsur birokrasi dan legislatif yang terdiri dari Dinas Pendidikan, dan anggota DPRD. (Hasbullah, 2007)

Secara lebih spesifik, pada Pasal 56 Undang-Undang Sistem Pendidikan Nasional Nomor 20 Tahun 2003, disebutkan bahwa di masyarakat ada Dewan Pendidikan dan Komite Sekolah atau Komite Madrasah, yang berperan sebagai berikut: (1) Masyarakat berperan dalam peningkatan mutu pelayanan pendidikan yang meliputi perencanaan, pengawasan, dan evaluasi program pendidikan melalui Dewan Pendidikan dan Komite Sekolah/Madrasah. (2) Dewan Pendidikan sebagai lembaga mandiri dibentuk dan berperan dalam peningkatan mutu pelayanan pendidikan dengan memberikan pertimbangan, arahan, dan dukungan tenaga, sarana, dan prasarana serta pengawasan pendidikan di tingkat nasional, provinsi, dan kabupaten/kota yang tidak mempunyai hubungan hierarkis. (3) Komite Sekolah/Madrasah sebagai lembaga mandiri dibentuk dan berperan dalam peningkatan mutu pelayanan dan memberikan pertimbangan, arahan dan dukungan tenaga, sarana, dan prasarana serta pengawasan pendidikan pada tingkat satuan pendidikan.

Secara lebih tegas, fungsi Komite Sekolah, dijelaskan dalam Kepmendiknas Nomor 044/U/2000, yakni sebagai berikut:

1. Mendorong tumbuhnya perhatian dan komitmen masyarakat terhadap penyelenggaraan pendidikan yang bermutu,

2. Melakukan upaya kerja sama dengan masyarakat, baik perorangan/organisasi/dunia usaha/dunia industri dan pemerintah berkenaan dengan penyelenggaraan pendidikan yang bermutu,

3. Menampung dan menganalisis aspirasi, ide, tuntutan dan berbagai kebutuhan pendidikan yang diajukan oleh masyarakat,

4. Memberikan masukan, pertimbangan, dan rekomendasi kepada satuan pendidikan mengenai:

a. Kebijakan dan program pendidikan,

b. Rencana Anggaran Pendidikan dan Belanja Sekolah (RAPBS),

c. Kriteria kinerja satuan pendidikan,

d. Kriteria tenaga pendidikan,

e. Kriteria fasilitas pendidikan,

f. Hal-hal lain yang terkait dengan pendidikan.

5. Mendorong orang tua dan masyarakat berpartisipasi dalam pendidikan guna mendukung peningkatan mutu dan pemerataan pendidikan,

6. Menggalang dana masyarakat dalam rangka pembiayaan penyelenggaraan pendidikan di satuan pendidikan,

7. Melakukan evaluasi dan pengawasan terhadap kebijakan, program, penyelenggaraan dan keluaran pendidikan di satuan pendidikan.

Komite Sekolah diharapkan dapat melaksanakan peran dan fungsinya sebagai penunjang dalam pelaksanaan proses pembelajaran yang sejalan dengan kondisi dan permasalahan lingkungan masing-masing sekolah. Komite Sekolah dapat melaksanakan fungsinya sebagai partner dari kepala sekolah dalam mengadakan sumber-sumber daya pendidikan dalam rangka melaksanakan pengelolaan pendidikan yang dapat memberikan fasilitasi bagi guru- 
guru dan siswa untuk belajar sebanyak mungkin sehingga pembelajaran menjadi semakin efektif. Adanya sinergi antara Komite Sekolah dengan sekolah menyebabkan lahirnya tanggung jawab bersama antara sekolah dan masyarakat sebagai mitra kerja dalam membangun pendidikan. Dari sini masyarakat akan dapat menyalurkan berbagai ide dan partisipasinya dalam memajukan pendidikan di daerahnya.

Keangotaan Komite Sekolah terdiri dari unsur masyarakat yang dapat berasal dari; perwakilan orang tua/wali murid berdasarkan jenjang kelas yang dipilih secara demokratis, para tokoh masyarakat (Ketua RT/RW/RK, kepala dusun, ulama, budayawan, pemuka adat, dan sebagainya), anggota masyarakat yang mempunyai perhatian atau dijadikan figur dan mempunyai perhatian untuk meningkatkan mutu pendidikan, pejabat pemerintah setempat (Kepala Desa/Lurah, Kepolisian, Koramil, Depnaker, Kadin, dan instansi lain), pakar pendidikan yang mempunyai perhatian pada peningkatan mutu pendidikan, organisasi profesi tenaga pendidikan (PGRI, Badan Pertimbangan Pendidian, ISPI, dan lain-lain), perwakilan siswa bagi tingkat SMP/MTs/SMA/MA/SMK yang dipilih secara demokratis berdasarkan jenjang kelas, dan perwakilan forum alumni SD/SLTP/SLTA yang telah dewasa dan mandiri. Anggota Komite Sekolah yang berasal dari unsur dewan guru, yayasan/lembaga penyelenggara pendidikan, Badan Pertimbangan Desa, sebanyak-banyaknya berjumlah tiga (3) orang. Dan jumlah anggota Komite Sekolah sekurang-kurangnya sembilan (9) orang dan jumlahnya harus ganjil. Syarat-syarat, hak, dan kewajiban, serta masa keanggotaan Komite Sekolah ditetapkan di dalam Anggaran Dasar (AD) dan Anggaran Rumah Tangga (ART). (Hasbullah, 2007). Dengan pemberdayaan Komite Sekolah secara optimal, termasuk dalam mengawasi penggunaan keuangan, transparansi penggunaan alokasi dana pendidikan lebih dapat dipertanggungjawabkan. Pengembangan pendidikan secara lebih inovatif juga akan semakin memungkinkan disebabkan lahirnya ide-ide cemerlang dan kreatif dari semua pihak terkait (stakeholder) pendidikan yang bersangkutan. (Saepudin, 2009)

\section{Struktur Komite Sekolah}

Struktur kepengurusan Komite Sekolah ditetapkan berdasarkan AD/ART yang sekurangkurangnya terdiri atas seorang ketua, sekretaris, dan bendahara. Apabila dipandang perlu, kepengurusan dapat dilengkapi dengan bidang-bidang tertentu sesuai kebutuhan yang ada. Selain itu, dapat pula diangkat petugas khusus yang menangani urusan administrasi. Struktur organisasi Komite Sekolah menggambarkan tugas-tugas yang menjadi kepedulian Komite Sekolah. (Saepudin, 2009)

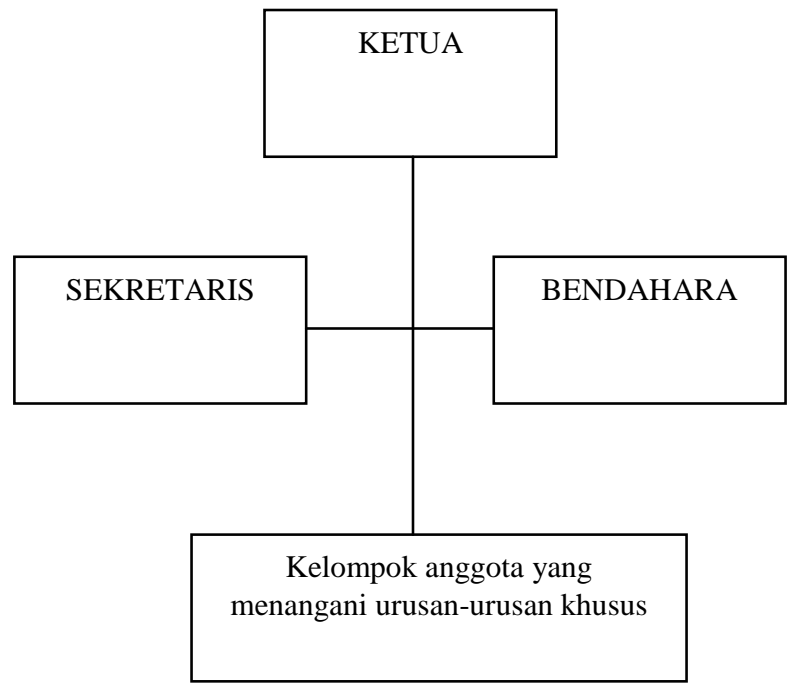

Gambar 1. Struktur Organisasi Komite Sekolah 


\section{Metodologi Penelitian}

Penelitian ini menggunakan metode kualitatif, yaitu mengkaji pemberdayaan Komite Sekolah dengan menganalisa data yang telah ada atau telaah pustaka. Tujuan penelitian dilakukan untuk mengkaji pemberdayaan Komite Sekolah dalam hal: (1) mewadahi dan menyalurkan aspirasi dan prakarsa masyarakat dalam melahirkan kebijakan operasional dan program pendidikan di satuan pendidikan, (2) meningkatkan tanggungjawab dan peran masyarakat dalam penyelenggaraan pendidikan, dan (3) menciptakan suasana dan kondisi transparan, akuntabel, dan demokratis dalam penyelenggaraan dan pelayanan pendidikan yang bermutu di satuan pendidikan. Langkah-langkah yang dilakukan dalam penelitian ini adalah: (1) melakukan pengkajian secara spesifik hal-hal yang terkait dengan pemberdayaan masyarakat dalam proses pendidikan, khususnya mengenai keberadaan Komite Sekolah dan Dewan Pendidikan, (2) data yang diperoleh dari studi kepustakaan dianalisis dan disusun secara spesifik, dan (3) merumuskan dan merekomendasikan hasil penelitian ini, terutama untuk kepentingan pihak-pihak terkait di dalam institusi sekolah.

\section{Hasil dan Pembahasan}

Dalam upaya mengaplikasikan transformasi konsep Komite Sekolah memerlukan proses bertahap dari waktu ke waktu, mulai dari tingkat menyadarkan perlunya fungsi Komite Sekolah baik kepada masyarakat maupun kepada penyelenggara pendidikan sebagai salah satu peluang bentuk partisipasi masyarakat di bidang pendidikan. Langkah selanjutnya adalah bagaimana menyebarluaskan konsep pelibatan publik dalam Komite Sekolah kepada masyarakat dan penyelenggara pendidikan. Selanjutnya adalah penyelenggara pendidikan melakukan konsultasi ke masyarakat untuk mendapat masukan dalam proses menetapkan kebijakannya.

Adanya kerjasama dari segenap potensi yang ada di masyarakat secara sinergis dalam bentuk saran dengan penyelenggara pendidikan untuk memutuskan kebijakan. Pada tingkat tertinggi adalah tercapainya rasa saling memiliki, bahwa Komite Sekolah merupakan wadah pemecahan masalah bersama yang dihadapi dalam penyelenggaraan pendidikan. Pada tingkatan tertinggi ini, masyarakat ikut memutuskan dan memecahkan masalah tanpa ada peran oposisi. Resiko ini menempatkan perlunya kematangan kondisi internal penyelenggara pendidikan, perubahan tatanan dalam pola berpikirnya, mengedepankan demokrasi, keterbukaan, dan akuntabilitas, di samping prinsip lainnya yang harus dilaksanakan secara komperhensif. Setiap pihak terkait sangat diperlukan perannya sesuai dengan kewenangan yang telah didelegasikan kepadanya, responsibilitas yang telah ditugaskan kepadanya, dan akuntabilitas yang melekat pada diri masing-masing.

Kondisi lingkungan strategis penyelenggaraan pendidikan di tingkat lokal menduduki posisi sentral, yang tentunya akan berbeda di masing-masing sekolah dan daerah. Pelaksanaan Komite Sekolah seakan berhadapan dengan identifikasi lingkungan strategis ini sebagai potensi awal, untuk menuju kondisi yang diinginkan, di masa depan yang jelas diketahui bahwa hal tersebut tidak dapat diharapkan sebagai penyebab berubahnya pola pikir dan pola tindak berbagai pihak terkait dalam jangka waktu yang pendek.

Saat ini penyelenggaraan pendidikan di sekolah memerlukan pelaksanaan prinsip keterbukaan, demokratis, tercapainya hasil guna, cepat tanggap, partisipasi, berwawasan ke depan, penegakan hukum, akuntabilitas, keadilan dan profesionalisme. Prinsip-prinsip ini tidak bisa dijalankan sebagian-sebagian menurut keinginan masing-masing dan meninggalkan beberapa prinsip lainnya. Sebab, apabila penyelenggaraan pendidikan menyisihkan beberapa prinsip tersebut, akan timbul ketidakseimbangan pelayanan oleh penyelenggara pendidikan dan keinginan masyarakat. (Hasbullah, 2007) 
Komite Sekolah selalu akan berhadapan dengan realitas adanya jalan panjang yang harus ditempuh secara bertahap. Kondisi yang demikian memerlukan komitmen dan dukungan fasilitas yang konsisten dan berkesinambungan. Pihak-pihak terkait pun perlu mengukur dari waktu ke waktu dan menggunakan proses yang serasi dengan kondisi lokalnya, apa yang sudah dihasilkan, apa yang sudah dicapai, apa yang masih kurang, dan bagaimana prospek Komite Sekolah ke depannya dalam penyelenggaraan pendidikan. Dengan demikian, selain keberadaannya yang sangat diperlukan, Komite Sekolah juga diharapkan dapat berjalan secara efektif dan efisien.

Masyarakat merupakan lingkungan manusia bagi pendidikan. Di era demokrasi dan demokratisasi saat ini, posisi masyarakat dalam kerangka pembangunan pendidikan mengalami penguatan. Masyarakat semakin menjadi komunitas pendidikan yang khas, dan mengambil peran penting bagi pencerdasan generasi muda. Komunitas pendidikan, juga dikenal sebagai pendidikan berbasis masyarakat atau pembelajaran dan pengembangan berbasis komunitas. Fenomena di Indonesia secara kekinian, konsep partisipasi masyarakat merupakan salah satu tema utama reformasi pendidikan dan pengelolaan sekolah di berbagai jenis dan jenjang pendidikan. Esensi pendidikan berbasis masyarakat akan semakin kuat sejalan dengan keputusan politik desentralisasi pemerintahan. Praksis ini dilegitimasi dalam Undang-Undang Nomor 20 Tahun 2003 tentang SISDIKNAS yang menyebutkan bahwa "pendidikan berbasis masyarakat adalah penyelenggaraan pendidikan berdasarkan kekhasan agama, sosial, budaya, aspirasi, dan potensi masyarakat sebagai perwujudan pendidikan dari, oleh, dan untuk masyarakat".

Inti dari pemberdayaan masyarakat adalah untuk pemunculan daya atau penguatan pada yang lemah. Pemberdayaan itu sendiri merupakan proses, di mana kekuatan masyarakat dalam pengambilan keputusan lebih dominan, dan dalam pelaksanaannya peranan masyarakat lebih diutamakan. Hal ini mungkin dicapai dengan menguatkan kapasitas masyarakat melalui pemberian kesempatan, keahlian, dan pengetahuan sehingga mampu untuk menggali dan memanfaatkan potensi-potensi yang dimiliki. Dengan kata lain, pemberdayaan adalah upaya untuk membangun daya itu, dengan mendorong, memotivasi dan membangkitkan kesadaran akan potensi yang dimilikinya serta berupaya untuk mengembangkannya melalui partnership, kerjasama yang mendalam, dan bekerja sama dengan pihak-pihak lain.

Bagi pemerintah dan pemerintah daerah, menyediakan anggaran untuk pembangunan pendidikan adalah kewajiban, bukan pilihan atau sekedar bantuan operasional. Perlu ditegaskan dan diketahui dengan jelas bahwa tidak ada yang gratis dalam pembangunan dan penyelenggaraan pendidikan. Persoalan esensialnya adalah siapa yang membayar. Ketika pemerintah membayar semuanya, di sinilah masyarakat menikmati pendidikan secara gratis. Sebaliknya, ketika pemerintah mengalokasikan anggaran serba sedikit untuk pendidikan, maka muncullah praktik yang dinamakan privatisasi pendidikan. Pemerintah menyadari bahwa dalam rangka mencapai tujuan pendidikan nasional melalui upaya peningkatan mutu, pemerataan, efisiensi penyelenggaraan pendidikan, dan demokratisasi pendidikan, perlu adanya dukungan dan peran serta masyarakat yang lebih optimal. Dukungan dan peran serta masyarakat selama ini sudah terbangun, namun demikian peran dan fungsinya lebih lanjut perlu diperluas, yakni melalui pembentukan dan aktualisasi fungsi Komite Sekolah dan Dewan Pendidikan sehingga mampu bekerja secara maksimal.

\section{Simpulan dan Saran}

Adanya Keputusan Menteri Pendidikan Nasional Nomor 044/U/2002 merupakan acuan pembentukan Komite Sekolah. Disebut acuan, karena pembentukan Komite Sekolah di berbagai satuan pendidikan disesuaikan dengan kondisi masing-masing satuan pendidikan atau kelompok satuan pendidikan. Oleh karena itulah, Komite Sekolah pada setiap satuan 
pendidikan harus dibentuk berdasarkan prakarsa masyarakat sekitar yang peduli dengan pendidikan, dan bukan atas arahan atau instruksi dari lembaga pemerintah. Fungsi Komite Sekolah sebagai suatu badan atau forum resmi untuk mengakomodasikan atau menyalurkan dan membahas hal-hal yang menyangkut kepentingan kelembagaan sekolah. Dibentuknya Komite Sekolah sebagai konsekuensi untuk mengakomodasi aspirasi, harapan, dan kebutuhan stakeholder sekolah. Selama ini aspirasi orang tua dan masyarakat kurang terserap oleh pihak sekolah, sehingga muncul pemikiran tentang perlunya dikembangkan wadah untuk menampung dan menyalurkan aspirasi masyarakat. Wadah tersebut, yakni Komite Sekolah yang diharapkan berfungsi sebagai forum di mana representasi para stakeholder sekolah terwakili secara proposional.

Hubungan sekolah dengan Komite Sekolah bukanlah suatu lembaga yang terpisah dari masyarakat. Sekolah merupakan lembaga yang bekerja dalam konteks sosial. Sekolah mengambil peserta didik dari masyarakat setempat, sehingga keberadaannya bergantung dari dukungan sosial dan finansial masyarakat. Oleh karena itu, hubungan sekolah dan masyarakat merupakan salah satu komponen penting dalam keseluruhan kerangka penyelenggaraan pendidikan. Adanya hubungan yang harmonis antar sekolah dan masyarakat yang diwadahi dalam organisasi Komite Sekolah, diharapkan mampu mengoptimalkan peran serta orang tua dan masyarakat dalam memajukan program-program pendidikan.

Dalam menjalin kerjasama dengan masyarakat hendaknya dilandasi dengan kesamaan tanggungjawab dan tujuan di antara lembaga pendidikan dan pihak masyarakat bersangkutan. Karena bagaimanapun juga sekolah adalah milik masyarakat, karena raw input sekolah itu sendiri berasal dari masyarakat, dan output sekolah kelak nantinya akan kembali kepada masyarakat. Jadi masyarakat ikut menaruh kepentingan dan bertanggungjawab terhadap kelangsungan penyelenggaraan pendidikan di satuan-satuan pendidikan, baik secara langsung maupun tidak langsung. Oleh karena itu, peran serta masyarakat perlu diberdayakan karena dapat menunjang pelaksanaan pendidikan, dalam bentuk pembinaan moral, bakat, pengajaran, maupun budaya. Pemberdayaan masyarakat tersebut akan bermanfaat bagi sekolah, apabila interaksi atau hubungan sekolah dengan masyarakat berlangsung efektif. Sebab pada hakikatnya Komite Sekolah atau Dewan Sekolah dan Dewan Pendidikan dibentuk untuk membantu mensukseskan kelancaran proses belajar-mengajar di sekolah, baik menyangkut perencanaan, pelaksanaan, maupun penilaian. Sehingga apa yang dilaksanakan di sekolah dapat sejalan dan selaras dengan kebutuhan dan perkembangan masyarakat. Hubungan baik dengan masyarakat akan tumbuh jika masyarakat juga merasakan manfaat dari keikutsertaannya dalam program pendidikan yang berlangsung di sekolah. Manfaat di sini dapat diartikan luas, termasuk rasa diperhatikan dan rasa puas karena dapat menyumbangkan kemampuannya bagi kepentingan sekolah. Implikasi dari hubungan sekolah dengan masyarakat akan membuahkan hasil berupa kerja sama, yang dapat terlaksana dengan baik sehingga dapat terus mendukung fungsi dan tujuan dari sekolah serta tetap memenuhi kepentingan bersama.

Sejak awal dibentuknya Komite Sekolah, partisipasi masyarakat seakan menjadi kata kunci untuk memecahkan masalah di sekolah. Keberadaan Komite Sekolah sesungguhnya merupakan harapan besar dalam pengembangan sekolah dan pemberdayaan masyarakat. Pembentukan Komite Sekolah dianggap efektif sebab pihak sekolah, masyarakat dalam hal ini orang tua atau pihak-pihak yang berkepentingan (stakeholder) dapat terlibat langsung dalam memikirkan, membahas, membuat keputusan, serta melakukan evaluasi yang berkelanjutan terkait dengan program-program yang di buat oleh sekolah. Kenyataan yang ada menunjukkan secara kualitatif kinerja operasional beberapa Komite Sekolah dan Dewan Pendidikan masih belum memenuhi harapan masyarakat. Kinerja itu masih sangat variatif. Sebab itu perlu difokuskan pada upaya saling membantu, saling membutuhkan, dan 
dibutuhkan atau adanya kebergantungan (interdepedence), yang didasari oleh moralitas yang tinggi dalam bentuk kejujuran, saling percaya dan keterbukaan dalam kesetaraan dalam upaya memecahkan segala masalah yang dihadapi sekolah sehingga dapat melahirkan keputusan terbaik yang mendasar dan bersifat jangka panjang dan tidak merugikan pihak manapun yang terkait di dalamnya.

Melalui wadah Komite Sekolah atau Dewan Sekolah ini, keterlibatan masyarakat di dalam sekolah tetap memperoleh peran yang cukup besar. Masyarakat diakui sebagai bagian dari proses pendidikan yang berlangsung. Diharapkan para stakeholder pendidikan mengambil peran yang maksimal, sehingga sekolah mampu memberikan yang terbaik bagi para customer-nya. Perlu disadari bahwa efektivitas peran masyarakat dalam wadah ini sangat bergantung kepada kreativitas dari lembaga tersebut dalam melahirkan dan menjalankan bentuk-bentuk dukungannya terhadap program-program sekolah.

Makna kreativitas dalam kelembagaan Komite Sekolah atau Dewan Sekolah melekat pada orang-orang yang mengisi organisasi termaksud, proses-proses kegiatan yang dijalankannya, dan terakhir yang terpenting adalah produk-produk yang dihasilkan oleh lembaga Komite Sekolah atau Dewan Sekolah tersebut. Karenanya perlu dipertegas bahwa kelembagaan Komite Sekolah atau Dewan Sekolah ini haruslah diisi oleh orang-orang yang kreatif, mau bekerja sama, dan ikhlas berkorban demi kepentingan sekolah dan masyarakat, sehingga seluruh kegiatan-kegiatan yang dijalankannya benar-benar mengarah pada bantuan pelaksanaan kegiatan program sekolah, dan pada akhirnya sekolah sesuai dengan harapan semua pihak yag berkepentingan dapat melahirkan keluaran-keluaran yang mencerminkan upaya sungguh-sungguh dan kerja kerasnya.

\section{Daftar Pustaka}

Hasbullah. (2007). Otonomi Pendidikan Kebijakan Otonomi Daerah dan Implikasinya terhadap Penyelenggaraan Pendidikan. Jakarta: PT Raja Grafindo Persada.

Pusat Bahasa Departemen Pendidikan Nasional. (2005). KBBI Kamus Besar Bahasa Indonesia. Edisi ke-3. Jakarta: PT (Persero) Penerbitan dan Percetakan Balai Pustaka.

Saepudin, Asep. (2009). Manajemen Kemitraan Sekolah dengan Masyarakat (Telaah Konsep, Strategi, \& Aplikasi). Bandung: PT Sarana Panca Karya Nusa.

Undang-undang SISDIKNAS. (2003). Undang-Undang Nomor 20 Tahun 2003 Tentang Sistem Pendidikan Nasional. Jakarta.

Undang-Undang Republik Indonesia Nomor 14 tahun 2005. (2010). Bandung: Citra Umbara. 